\title{
Kangaroo Mother Method: Mothers' Experiences and Contributions to Nursing
}

\author{
João Carlos Arivabene ${ }^{1}$ \\ Maria Antonieta Rubio Tyrrell ${ }^{2}$
}

\begin{abstract}
This research aimed to describe mothers' experiences, analyzing them in the light of the principles of the Kangaroo Mother Method (KMM), and discuss the mothers' contributions based on the meanings of these experiences for nursing actions. In data collection, a questionnaire was used that characterized the mothers' socioeconomic profile and, through focus groups, stories were obtained about the benefits of these experiences, which supported the construction of the following categories: survival and recovery of the baby; the mothers' daily life modified by the KMM and valuation of affective family bonds in the KMM. The experiences are related to increased bonding between mother and baby, reduction of the infant's time of separation from the family, besides leading to increased competition and confidence in the parents to take care of their child, even before discharge, improving the mother's relation with the family, inside the family and with the team that takes care of the baby.
\end{abstract}

Descriptors: Kangaroo Mother Care; Maternal Experiences; Nursing Care; Nursing.

\footnotetext{
${ }^{1}$ M.Sc., in Nursing, e-mail: jcarivabene@yahoo.com.br.

2 Ph.D. in Nursing, Full Professor, Escola de Enfermagem Anna Nery, Universidade Federal do Rio de Janeiro, RJ, Brazil, e-mail: tyrrell2004@ig.com.br.
}

Corresponding Author: João Carlos Arivabene Faculdade Pitágoras - Unidade de Linhares Rua São Mateus, 1458 Araça 


\section{Método mãe canguru: vivências maternas e contribuições para a enfermagem}

O objetivo deste estudo foi descrever vivências das mães, analisando-as à luz dos princípios do Método da Mãe Canguru (MMC) e discutir as contribuições das mães a partir dos significados dessas vivências para as ações de enfermagem. Na coleta dos dados, empregou-se questionário que caracterizou o perfil socioeconômico das mães e, por meio da técnica grupo focal, obtiveram-se relatos dos benefícios dessas vivências que subsidiaram a construção das categorias: sobrevivência e recuperação do bebê, o dia a dia das mães modificado pelo MMC e valorização dos laços afetivos familiares no MMC. Constatou-se que as vivências estão relacionadas ao aumento do vínculo entre a mãe e o bebê, à diminuição do tempo de separação do recém-nascido da família, além de proporciona maior competência e confiança aos pais nos cuidados com seu filho, mesmo antes da alta hospitalar, melhorando o relacionamento da mãe com a família, entre eles e com a equipe que cuida do bebê.

Descritores: Método Mãe Canguru; Vivências Maternas; Cuidados de Enfermagem; Enfermagem.

\section{Método madre canguro: vivencias maternas y contribuciones para la enfermería}

El objetivo de este estudio fue describir vivencias de las madres, analizándolas bajo los principios del Método de la Madre Canguro (MMC) y discutir las contribuciones de las madres a partir de los significados de esas vivencias para las acciones de enfermería. En la recolección de los datos, se empleó un cuestionario que caracterizó el perfil socioeconómico de las madres y, por medio de la técnica grupo focal, se obtuvieron relatos de los beneficios de esas vivencias que subsidiaron la construcción de las categorías: sobrevivencia y recuperación del bebé; el día a día de las madres modificado por el MMC; y, valorización de los lazos afectivos familiares en el MMC. Se constató que las vivencias están relacionadas al aumento del vínculo entre la madre y el bebé, a la disminución del tiempo de separación del recién nacido de la familia, además de proporcionar mayor competencia y confianza a los padres en los cuidados con su hijo, inclusive antes del alta hospitalaria, mejorando las relaciones de la madre con la familia, entre ellos y con el equipo que cuida del bebé.

Descriptores: Cuidado Madre Canguru; Vivencias Maternas; Atención de Enfermería; Enfermería.

\section{Initial considerations}

Around the world, 20 million preterm and/or lowbirth weight children (less than 2,500g at birth, without considering gestational age) are born every year. One third of them dies before reaching one year of age ${ }^{(1)}$. Preterm birth (infant who did not complete 37 weeks of gestation, despite birth weight, classified in: mild preterm birth - 35 to 37 weeks unfinished; moderate preterm birth - 31 to 34 weeks of gestation; extreme preterm birth - less than 30 weeks of pregnancy)(2), represents a great child health problem for infants.

In the context of the epidemiological process of prematurity, mainly in neonatal issues, since 1979, at the Maternal-Infant Institute in Bogota (Colombia), doctors Edgar Rey Sanabria and Héctor Martinez Gómez have been concerned with the standardization of the Kangaroo Mother Method (KMM) which, at that time, was aimed at reducing maternal mortality.

In the last three decades, KMM has been used 
in different countries, mainly those with insufficient incubators and human resources to guarantee highquality care to low-birth weight infants (LBWI). In those countries, the basic goal was to discharge the LWPIs early in view of the critical situation they went through(3).

In Brazil, the first services that developed KMM were Hospital Guilherme Álvaro in Santos, SP (1992) and the Maternal-Infant Institute in Recife, PE (1993). Based on those successful experiences, the method expanded to a considerable extent in Brazil, due to the advantages it offers for mothers and infants, although Brazilian policies put more emphasis on benefits related to the infant: it decreases the infant's time of separation from the family, avoiding long periods without sensory stimulation, makes parents more competent and confident to handle their child, even before discharge from hospital, facilitates the child's thermal control, decreases diseases and hospital infections, favoring a shorter hospital stay for the infant, among other benefits, as defined in the Humanized Care Standard for Low-Birth Infants - Kangaroo Method -Decree No 693, July $5^{\text {th }} 2000^{(4)}$.

Based on the understanding that the birth of a child, mainly when preterm (gestational age less than 38 weeks) and often dependent on professional and/ or maternal care, transforms the family organization, demanding adaptations in their daily life, involving these relatives' internal and external relations, in this research, it is considered that nursing plays a fundamental role in KMM, with clarifications and changes in conceptions and care practices for LWPI. This favors knowledge, among others, about paternal and maternal and, why not, supportive rights and duties.

In that context, the mother, father, infant and relatives are experiencing moments of crisis in their lives, inserted in a social, economic, spiritual and cultural environment. Thus, mothers and their relatives should be heard with regard to their doubts and difficulties, anxieties and concerns, which is only possible based on the acknowledgement of the family reality, with a view to the understanding of the health-disease-health process and family (re)integration, in response to the biopsychosocial needs of the people involved.

According to KMM, "only systems that permit early contact between the infant and his mother/relatives will be considered as 'Kangaroo Method', with advice and supervision, freely chosen by the family, in an increasing and safe way"(3). These people involved should be accompanied by a health team with adequate training, giving them dignified care and educational support and allowing them to exercise their citizenship, in compliance with KMM principles that are based on early discharge, independently of birth weight, provided that the infant is clinically stable; encouragement of early contact between mother and infant, who is placed between the mother's breast; and vertical placement of the infant.

Although KMM care originated in and was developed based on the infant's needs, the Brazilian standard covers humanized care to participants in the method, i.e. mother, infant, family and professionals involved(4).

In this care process to mothers and families, however, medical, nursing and other therapists' care is almost always highly valued and tends to be considered powerful. Hence, the institutional structure becomes authoritarian, in which the health team exerts dominant power on the woman/mother and family's cultural reality, seriously impairing care quality. These professionals develop educative and care actions that replace popular beliefs and practices, which are considered non-scientific and can negatively affect the care the child demands(5).

Based on the above, this research looked at mothers' experiences in the KMM set up at a public hospital in Greater Vitória, the capital of Espírito Santo, Brazil. The following goals were set: to describe the mothers' experiences in KMM, to analyze the mothers' experiences in the light of KMM principles, to discuss the mothers' contributions based on the meanings of their experiences in KMM for nursing actions.

\section{Theoretical-methodological framework}

This is a qualitative research. This approach makes it possible to incorporate meanings, motives, inspirations, beliefs, values and attitudes, understood here as a human phenomenon that is part of the involved people's social reality(6). This approach departs from the premise that a dynamic relation is built between the real world and the subject in this world, granting a subjective view of the subject to the objective world.

Adapting the method to the research and the scenario, the revealing case study was used, when the researcher has the opportunity to observe and analyze a phenomenon that was previously inaccessible to scientific research, The intention is to unveil some predominant phenomena which scientists had no access to until then. This method permits seeing what these social actors' daily reality is like. Moreover, the case study method allows for broad and detailed knowledge on the object, is very flexible and refers to the ability to deal with a wide range of evidence witnessed while developing the $\operatorname{research}^{(7)}$. 
The research actors were 13 mothers of lowweight preterm infants attended in the three phases (first phase: Neonatal Intensive Care Unit (NICU) and Intermediary Unity; second phase: Kangaroo RoomingIn; third phase: Follow-Up - Home Kangaroo Care) of KMM, between 2000 and 2005. During this period, the method was developed fully and completely in the selected scenario, in terms of structural organization as well as human resources.

Data were collected between November 2006 and March 2007. The actors participated voluntarily. They were previously contacted to receive information about the project and ethical care in the research process. Data collection covered two phases. In the first, a questionnaire was applied through individual interviews, including questions about sociodemographic characteristics aimed at characterizing the research actors and the scenario.

After this individual moment, the mothers were joined for collective interviews (second phase), when the focus group strategy was applied, which is "a form of collecting data directly from a group's discourse, which reports on its experiences and perceptions about a theme of collective interest"(8). It is adequate for relations in families, work teams and interpersonal networks and favors the dialectical elaboration of group thinking(9).

In the focus groups, each research group met in one session, with an average duration of one hour and a half. Meetings took place at a neutral place - auditorium of the research hospital, outside the participants' daily atmosphere and with easy access, without noise, so that discourse could be recorded without interference. Initially, the idea was to include six to eight interviewees in each group, in response to the need to collect data of collective interest that contribute to the construction of empirical and analytic categories.

Due to some interviews weather difficulties (excessive rains) and time constraints, two groups with four interviewees and one with five were held, totaling the 13 mothers of infants attended by the KMM who participated in this research.

This research is in accordance with Resolution No $196 / 96$ by the National Health Council about research involving human beings ${ }^{(10)}$. The study was approved by the CEP/EEAN/HESFA/UFRJ and by the institution where the research was carried out. The mothers signed the free and informed consent term, showing their agreement to participate in the research.

The study was carried out at a public state hospital located in Serra, a city in Greater Vitoria, in Espírito
Santo State, Brazil. This institution is part of the Unique Health System (SUS). It is also a tertiary referral hospital for care delivery to pregnant, parturient and puerperal women and high-risk newborns.

Based on the preliminary results, the following theme categories were constructed: a) benefits of experiences in KMM: the infant's survival and recovery; b) the mothers' daily life modified by the kangaroo mother method; c) valuation of affection among relatives; d) difficulties experienced in KMM; e) benefits of experiences related to the nursing team and $f$ ) mothers' comments and suggestions. In this article, the first three categories will be discussed.

\section{Results analysis and discussion}

\section{The mothers' sociodemographic profile}

The following characteristics were found: ages ranged between 18 and 40 years, with a prevalence of mothers aged 33 years or older. Ten of the interviewees were married $(76.9 \%$, mostly $(69.2 \%)$ housewives and with insufficient (between one and three minimum wages) family income $(69.2 \%)$, impairing the progression of social, economic, cultural and family development and acquisition of treatment for the infant (consultations, therapies, medication, among others) when these are not offered by the SUS. As for education, $92.3 \%$ had finished the first or second year of primary education. Education in this population remains unsatisfactory. Most participants were evangelical (61.5\%) and, in that perspective, it is considered in this research that people in risk situations value beliefs and their religious values.

\section{Theme categories}

Benefits of experiences in the kangaroo mother method: the infant's survival and recovery

The mothers highlighted, expressed and affirmed that adherence to the method was for the sake of the infant's survival and recovery. These mothers' primary concern is their preterm infant's survival. It is highlighted that the mothers' adherence to KMM is accompanied by fear, anxiety and a feeling of guilt, which can impair the method's process and this mother's social relations with other people involved in $\mathrm{KMM}^{(11)}$. That situation is confirmed in the following group statements.

[...] the baby develops better and recovers his weight faster.

[...] He needs love, affection, contact with me. 
According to the mothers, health team professionals (social worker, nurse, physician) suggested adherence to the method and, for one of the mothers, this suggestion came from her husband. In this process, there is not one single discourse about the health teams participation - that is, the mothers' statements refer to isolated professionals, and not belonging to an interdisciplinary team. Not all mothers agreed to participate in KMM, although they adhered because of the benefits for the infant. Five mothers affirmed they faced many difficulties, but also adhered to the method because of its benefits for the infant's survival. Another situation that should be considered is the professional/team's approach towards adherence to the method, justifying the need to adhere because of the advantages for the baby, as identified next.

[...] develop, grow, gain weight, when we pick up the baby, what we most want is that he regains weight, because if he doesn't regain a certain weight he won't leave.

[...] ah, you have to do it because of your daughter, so that she gets heavier, it protects more [...] they said: do the method and your daughter will develop faster, gain weight, grow. So I did that.

The mothers' daily life modified by the kangaroo mother method

The mothers explained that they made all possible efforts to see to their babies' needs. It is understandable that many of these women/mothers get afflicted by abandoning their other children, husband, job or course, to dedicate themselves almost exclusively to care for the preterm infant. Thus, they may give up their role as woman, worker or wife. This situation may cause a state of vulnerability in mothers and relatives and lead to the occurrence of social, cultural, economic disorders, among others, as evidenced next:

[...] it was very difficult, but it was worth it. I even abandoned my house and my other kids.

[...] I lived exclusively for him (baby, justifying that he needed her care more).

About family life, three mothers explained that their husband or other relatives (mother-in-law, siblings, mothers) did not incorporate the KMM, complicating the relation between the mother and other social beings, as observed in the following statements.

[...] my adolescent daughter, so it really was a lot of suffering, because I accumulated concern with the baby and my husband used to get into trouble, everything got into my head.

In those relations when relatives were thoughtful and collaborative, on the other hand, they helped a lot in the development of the KMM, revealing citizenship in the health-disease-health process, as identified in the following statements.

[...] A couple of ministers adopted us, me, my husband and my daughter, the minister's wife sent my other daughter to school, did her homework with her, washed the baby's clothes, I really needed it, it was very good.

[...] my mother was very special, she was always present, she was the one who advised me, she came here (hospital) with me all the time. [...] my family was primordial, it was everything.

Women/mothers' harsh reality is acknowledged as, besides playing the role of mothers/caregivers, they play other roles in society. Even in 2007, 13 years after the International Conference on Population and development ${ }^{(12)}$, practical advances remain far below the needs women experience, without perceiving the risk of getting ill or dying.

Another fact that should be highlighted is that the mothers deliver professional (formal) care, that is, the health professionals who assist them charge these mothers with activities/care acts which they should perform (bathing according to the technique, holding the baby for venipuncture, among others), as well as maternal (informal) care to their babies. The latter do entail an affective approach with their baby (changing diaper, caressing, among others), which are maternal goals and not tasks. In developing these activities, many of which are complex, the mothers feel overloaded. In most cases, these tasks are imposed without even discussing and proposing this care, as described below.

[...] When they had to "catch a vein", my God, it was so sad, I had to stay there and sometimes hold the baby to "pierce him".

[...] I came here (hospital) to take care of the baby and then I got home to help my seven-year old daughter to make dinner. [...] after I got home, I was tired, then I washed his clothes (baby) and the next day I had to go back to the hospital and take care of my baby.

Some mothers also reported that, when they were absent, the babies did not receive proper care and they did not receive complete and correct information, which made their relation with the professional team more difficult, as exemplified next.

[...] when I saw her and her head was skived, oh dear, it was terrible, and they explained me that it was because she had no vein, then I got really angry.

[...] I thought, oh my God, they didn't even change her diaper, she got all wet, then I got home, I didn't want to do anything, I just wanted to cry. 
Valuation of affection among relatives

This was characterized by improved contact, affection, understanding when the family members' effectively participated in KMM. In this sense, the researchers agree with some authors who consider that, in the family, the couple's love and mutual support is the main determinant of their children's education, in order to be able to perform the important task of establishing habits, attitudes and values(5). This constitutes the theoretical base for a better quality of life among the people involved, in which the families' actions are centered on the individual as a whole, considering social, economic and cultural transformations.

[...] the family and the neighbors, the strength they gave us, it helped a lot.

[...] everyone was very happy, praying, asking God, praying, campaigning and everything.

[...] the entire family cooperated, he (husband), my mother, my family, a lot of strength, a lot of support, a lot of hugs, a lot of caresses was what helped me a lot.

The direct relation between the mother and her child evidences that intimate contact with the preterm infant can positively interfere in this baby's relation with the world. These facts are exemplified in the following statements.

[...] they really grab onto us [...] we end up being overprotective [...] today he is really close to me. [...] they don't want to lose that bond anymore, of holding onto us, these children don't want to stay in their cot, they don't want to stay in their pram, they just want to stay with us, sleep with us.

From the perspective of contributions, in care terms, the educative and sociocultural dimension of care offered to LWPI is emphasized, guaranteeing the constitutional right to citizens' health to these clients. This contribution extends to health and especially to nursing professionals, guaranteeing quality in the relation between the care professional and the person receiving care.

\section{Final considerations}

When reflecting on the results in the light of the advantages mentioned in the 2000 standard about the KMM, it is observed that, according to the mothers' discourse, the reported experiences are evidenced, on the one hand related to: a) increased bonding between mother and infant; b) decreased time of separation between infant and family, avoiding long periods without the oversight of maternal care and c) improved relationship between mother and family, among family members and with the team that takes care of the baby.

When relating KMM results to the Humanization Program in Care Delivery to Preterm Infants, it can be inferred that the former remain very fragile with regard to professionals' technical security and adequate resources for the success of the method.

Based on the obtained results, family participation is considered essential for the success of the method. This participation should occur harmoniously in hospital (first and second phase) and at home (third phase), guaranteeing support, comfort, confidence and partnership to these women/mothers, in professional (formal) as well as in maternal (informal) care, when proposed by the health team. In that sense, the understanding of $\mathrm{KMM}$ indication and spontaneous adherence by the mother, thus avoiding situations of family crisis and stress, including job loss or school dropout.

In that sense, the nursing team should know the clients' socioeconomic profile, acknowledge the reality of the mother-family experience in its social context, valuing these persons' incorporation in the care process, and deliver care to the preterm infants and mothers. Therefore, nursing professionals need to know, understand and transform their care, in which mother-baby-family should be seen in their own culture, considering the need to promote nursing care in a crosscultural perspective.

Also, as the preterm infant serves as the protagonist in the KMM, according to the health policy, it is observed that nursing holds the woman-mother accountable to an excessive extent, not helping mothers to transform themselves or adapt to the situation of being a premature mother, causing disharmony in the relation, due to the lack of professional skills to acknowledge the mothers' and families' difficulties to adapt to the prematureness.

Thus, this research can serve as a reference point for future research and/or studies, strengthening the research line on Teaching and Care Policies and Models in Women and Infant Nursing and Health, favoring the development of educative and care actions that promote the civil role of those involved in KMM. 


\section{References}

1. Ministério da Saúde (BR). Política nacional de atenção integral a saúde da mulher: princípios e diretrizes. Brasília: Ministério da Saúde; 2004.

2. Marcondes E, Vaz FAC, Ramos JLA, Okay Y. Pediatria Básica: tomo I - pediatria geral e neonatal. 9.ed. São Paulo: Sarvier; 2003.

3. Almeida CM, Almeida AFN, Foiti EMP. Efeitos do método mãe canguru nos sinais vitais de recém-nascidos pré-termos de baixo peso. Rev Bras Fisioter. 2007; 11(1):1-5.

4. Ministério da Saúde (BR). Portaria n. ${ }^{\circ} 693$, de 5 de julho de 2000. Norma de atenção humanizada do recém-nascido de baixo peso. Brasília; 2005. [online]. [Acesso em: 15 março 2005]. Disponível em: http://www.saude.gov.br.

5. Elsen I, Monticelli M. A cultura como obstáculo: percepções da enfermagem no cuidado às famílias em alojamento conjunto. Texto e Contexto Enferm. 2006; 15(1):26-34.

6. Minayo MCS, Deslandes SF, Gomes R. Pesquisa social: teoria, método e criatividade. 25. ed. Revista e atualizada. Petrópolis -
Rio de Janeiro: Vozes; 2007.

7. Yin RK. Estudo de caso: planejamento e métodos. 3. ed. Porto Alegre: Bookman; 2005.

8. Leopardi MT, Thofehrn MB. Teoria dos vínculos profissionais: um novo modo de gestão em enfermagem. Rev Texto \& Contexto Enferm. 2006; 15(3):409-17.

9. Aschidamini IM, Saupe R. Grupo focal: estratégia metodológica qualitativa. Um ensaio teórico. Rev Cogitare Enferm. 2004; $9(1): 9-14$.

10. Ministério da Saúde (BR). Comissão Nacional de Ética em Pesquisa. Normas para pesquisa envolvendo seres humanos. Resolução CNS 196 / 96 e outras. Brasília: Conselho Nacional de Saúde; 2000. [Cadernos Técnicos].

11. Caetano LC, Scochi CGS, Angelo M. Vivendo no método canguru a tríade mãe-filho-família. Rev Latino-am Enfermagem. 2005; 13(4):562-8.

12. Conferência Internacional sobre População e Desenvolvimento. Relatório final. Cairo: CNPD; FNUAP; 1994. 